\title{
Personality and Coping in Groups With and Without Bulimic Behaviors
}

\author{
Tomaz Renata ${ }^{1}$ and Zanini Daniela S 2 \\ ${ }^{1}$ Alves Faria College \\ 2Pontifical Catholic University of Goias \\ Brazil
}

\section{Introduction}

Eating disorders have been increasing year by year, mainly due to social demands for anorexic standards of beauty (Cordás, 2004). Among the eating disorders, bulimia, described as episodes of binge eating followed by compensatory behaviors (Cordás, 2004), stands out.

Globalization and capitalism largely develop markets that explore beauty (for example, media, marketing strategies, chemical industries), and require their audience to follow a trend dictated by them (Souza \& Santos, 2007). That makes Wolf (1991) postulate beauty as a monetary system similar to gold, a cult of beauty and thinness which intensified the development of eating disorders such as bulimia.

Since Hippocrates, in 467 BC, Boulos was the terminology used to describe a sick hunger. But it was in 1743, when James described binge eating as "true boulimus", and bulimic episodes as "caninus appetites", that bulimia started to be studied in its relation to health (Cordás, 2004). However, the recognition of an eating disorder called bulimia nervosa only occurred in 1979. In that year, Russell described cases of this disease linked to anorexia nervosa. Both diseases are similar and, in most cases, appear as concurrent or comorbidities. However, in bulimia there is not extreme weight loss as in anorexia (Busse, 2004).

Bulimia is characterized by an excessive consumption of food which does not aim for satiation. The DSM-IV emphasizes two factors related to binge eating: quantitative and qualitative. The quantitative factor is related to the excess of food intake, an amount of food superior than people are used to or need to consume. The qualitative factor would be the lack of control characteristic of binge eating, in which the individuals cannot stop eating. Both factors are common in the bulimia disease.

In general, after a gorging food intake, the person experiences guilt and fear of gaining weight that can trigger compensatory behaviors like self-induced vomiting, overuse of laxatives, diuretics, thyroid hormones, anorectic drugs, diets and excessive exercise in order to avoid weight gain. In addition to these behaviors there is an increased dissatisfaction with their bodies, often leading to body image distortion (Chemin \& Milito, 2007).

Compensatory behaviors used by patients with bulimia generate considerable harm to their health. Among them we can mention severe changes in the central nervous system, changes in the cycle of satiation, metabolism and production of neurotransmitters (Chemin \& Milito, 2007; Sicchieri, Bighetti, Borges, Santos, Ribeiro, 2006). 
The causes of this disorder are not well-known. Authors like Claudino and Zanella (2005), Castilho, Gonçalves, Milk, and Cordás Segal (1995) describe a relation between bulimia and personality factors, such as impulsivity and affective instability that may be associated to the behaviors of uncontrolled binge eating and purging to avoid weight gain. Even "low selfesteem, self-negative evaluation and greater vulnerability to stress are important risk factors for developing eating disorders" (p.19).

The relationship between personality factors and bulimia is based on an understanding of the disorder from a dynamic perspective, which considered the influence of personality traits over behaviors that can be associated with bulimia (Leonidas and Santos, 2010). In this sense, the Big Five model has been the most widely used in the investigations of personality traits and its relationship to psychopathology. This model refers to the Theory of Personality Factors based on the Big Five model composed by the factors: neuroticism, extroversion, openness, agreeableness and conscientiousness (Nunes, 2005). Figure 1 describes the personality factors according to the model of the Big Five factors.

The applicability to different cultures and the easy comprehensibility of the Big Five concepts can explain the large spread of studies based on it (Tani, Greenman, Schneider \& Fregoso, 2003; \& Ruiz Jiménez, 2004). The Big Five model also provides a measure of personality traits that has proved to be valid in different studies, both to predict the level of physical well being, mental and social health of individuals, and to predict the usage of coping strategies (Costa \& Widiger, 1993).

For example, Furtado, Falcone and Clark (2003) found, in their studies, that dysfunctional personality factors such as perfectionism and obsessive-compulsive behavior interfere negatively in the way individuals cope with stress. In fact, we can postulate that the relation between personality and health can occur in at least two pathways. In the first one, by means of a direct effect, studies have shown a direct association between neuroticism and eating disorders (Tomaz \& Zanini, 2009), anxiety and depression (Forns \& Zanini, 2005), among others. In the second one, by means of an indirect effect, studies have demonstrated that individuals with high neuroticism scores have stronger tendencies to use avoidance as a way of coping with their problems, and that using this type of coping strategy is related to eating disorders (Tomaz \& Zanini).

Thus, one can say that avoidance coping may influence the manifestation of psychiatric diseases such as bulimia (Margis, Picon, Cosner \& Silveira, 2003; Nakahara, Yoshiuchi, Yamanaka, Sasaki, Suematsu, Kuboki, 2000), and that experiencing stressful situations can lead an individual to develop psychiatric disorders, such as posttraumatic stress, and depressive and anxiety symptoms, depending on the coping strategies they used (Blumenthal, Babyak, Carney, Keefe, Davis, Lacaille, Parekh, Freedland, Trulock Palmer, 2006, Sorkin \& Rook, 2006).

On the other hand, patients with eating disorders such as bulimia tend to use less adaptive coping strategies than the general population (Nakahara, Yoshiuchi, Yamanaka, Sasaki, Suematsu, Kuboki, 2000). That can be explained by the availability of individual coping resources. To Claudino and Zanella (2005) the effect that stressful events have on the process of eating disorders "(...) depends on the resources that the individual has prior to use in response, as well as the social support network that he has access to and which can function as a protective factor "(p.21).

According to the transactional theory, coping can be defined as a person's ability to cope with a stressful situation, which exceeds its own resources (Compas, 1987; Lazarus \& 


\begin{tabular}{|c|c|c|}
\hline Big Five Factors & Low & High \\
\hline $\begin{array}{l}\text { Neuroticism: evaluation of } \\
\text { the adjustment versus } \\
\text { emotional instability. } \\
\text { Identifies individuals prone } \\
\text { to psychological disorders, } \\
\text { unrealistic ideas, excessive } \\
\text { needs or cravings and } \\
\text { maladaptive responses. }\end{array}$ & $\begin{array}{l}\text { Quiet, relaxed, } \\
\text { unemotional, strong, } \\
\text { secure, self-satisfied, } \\
\text { stable. }\end{array}$ & $\begin{array}{l}\text { Worried, nervous, } \\
\text { emotional, insecure, } \\
\text { inadequate, } \\
\text { hypochondriac, tense, } \\
\text { unstable, unhappy. }\end{array}$ \\
\hline $\begin{array}{l}\text { Extroversion: evaluation of } \\
\text { the amount and quality of } \\
\text { interpersonal interactions, } \\
\text { activity level, need for } \\
\text { stimulation, and ability to } \\
\text { rejoice. }\end{array}$ & $\begin{array}{l}\text { Reserved, serious, closed, } \\
\text { aloof, task-oriented, } \\
\text { selfless, quiet, speechless, } \\
\text { non-assertive, non-bold, } \\
\text { non-energetic, shy. }\end{array}$ & $\begin{array}{l}\text { Sociable, active, talkative, } \\
\text { people-oriented, } \\
\text { optimistic, playful, } \\
\text { affectionate, assertive, } \\
\text { bold, energetic, fearless. }\end{array}$ \\
\hline $\begin{array}{l}\text { Opening: evaluation of } \\
\text { proactive activity and } \\
\text { appraisal of the experience, } \\
\text { tolerance and exploration, } \\
\text { enjoyment of new } \\
\text { experiences. }\end{array}$ & $\begin{array}{l}\text { Conventional, reasonable, } \\
\text { limited interests, non- } \\
\text { artistic, non-analytical, } \\
\text { non-imaginative, non- } \\
\text { creative, non-inquisitive, } \\
\text { non-reflective, non- } \\
\text { sophisticated. }\end{array}$ & $\begin{array}{l}\text { Curious, broad interests, } \\
\text { creative, original, } \\
\text { imaginative, } \\
\text { nontraditional, curious, } \\
\text { thoughtful, sophisticated. }\end{array}$ \\
\hline $\begin{array}{l}\text { Agreeableness: evaluation of } \\
\text { the amount of interpersonal } \\
\text { orientation over a continuum } \\
\text { from compassion to } \\
\text { antagonism in thoughts, } \\
\text { feelings and actions. }\end{array}$ & $\begin{array}{l}\text { Cynical, rude, suspicious, } \\
\text { uncooperative, vengeful, } \\
\text { ruthless, irritable, } \\
\text { manipulative, selfish, } \\
\text { stingy. }\end{array}$ & $\begin{array}{l}\text { Generous, kind, confident, } \\
\text { helpful, forgiving, gullible, } \\
\text { honest, cooperative, } \\
\text { altruistic. }\end{array}$ \\
\hline $\begin{array}{l}\text { Conscientiousness: } \\
\text { evaluation of the grade of } \\
\text { persistence, organization and } \\
\text { motivation to achieve his/her } \\
\text { objectives. }\end{array}$ & $\begin{array}{l}\text { Aimless, unreliable, lazy, } \\
\text { careless, negligent, } \\
\text { relaxed, weak, hedonistic, } \\
\text { disorganized, } \\
\text { irresponsible, impractical. }\end{array}$ & $\begin{array}{l}\text { Organized, reliable, } \\
\text { hardworking, self- } \\
\text { disciplined, punctual, } \\
\text { scrupulous, neat, } \\
\text { ambitious, persevering, } \\
\text { responsible, practical, } \\
\text { detail-oriented. }\end{array}$ \\
\hline
\end{tabular}

Fig. 1. Description of the Big Five Factors

Folkman, 1984). Coping is characterized by a dynamic process of mutual influence between person and environment and can be classified according to their focus on problem-focused strategies (seeking to modify the problem in order to solve it), and emotion-focused strategies (which seek to transform the emotions caused by the problem and not the problem itself) (Lazarus \& Folkman, 1984; Pesce, Assisi, Santos \& Oliveira, 2004). There are 
other categories to measure coping strategies such as classifying coping responses, according to their method, in cognitive responses (when using cognitive efforts to cope with a stressful situation) and behavioral responses (when using behavioral efforts to cope with a stressful situation) (Holahan, et al. 1996; Moos, 1993).

Moos (1993) built the Coping Response Inventory (CRI) linking method to focus, to conceptualize and measure coping strategies. The CRI classify coping strategies in cognitive and behavioral responses, and also in approach and avoidance coping. In the group classified as approach coping strategies are those that employ cognitive and behavioral responses as a way to solve the problem. This group is similar to that described by Lazarus and Folkman (1984) as problem-focused coping. Examples of these strategies are logical analysis, positive reappraisal, seeking guidance and problem solving (the first two refer to cognitive efforts and the last two to behavioral efforts).

In the group of avoidance strategies there are other specific strategies that can also be classified as cognitive and behavioral efforts to avoid the problem by manipulating the emotions that cause the problem without confronting the stressful situation. Again, this classification is similar to the emotion-focused coping described by Lazarus and Folkman (1984). Examples of this type of avoidance coping would be cognitive avoidance, acceptance and resignation, seeking alternative reward, and emotional discharge (again, the first two related to cognitive efforts and the last two to behavioral efforts).

Among the various factors related to eating disorders, literature has pointed to personality traits and coping strategies towards the problem as factors that may influence the occurrence, perpetuation and adherence to treatment (Binford, 2003; Gongora, Guedes, Albuquerque, Troccoli, Noriega, JJ \& Guedes, 2006; Rebelo \& Leal, 2007). However, the differential analysis of this influence on bulimic subjects in comparison to other groups is still unclear and could contribute to more effective interventions for this group.

This chapter discusses the relationship between personality and coping in a group of people with bulimic behavior (cases) compared with a group without bulimic behavior (controls), highlighting the implications of these differences for intervention proposals which are more suitable to the characteristics of the group studied.

\section{Method}

\subsection{Participants}

This is a case control study which included 166 participants, pre-screened in three higher education institutions in a city in central Brazil, and with no self-reported diagnosis of mental disorders. 62 of these presented bulimic behaviors, according to the Eating Attitude Test (EAT) score. This instrument has been described as effective in the identification of eating disorders (Nunes \& col., 2006; Tomáz \& Zanini, 2009). Therefore, those individuals with raw scores in the general EAT range above 21 were considered cases (as standardization of the instrument made by Nunes \& col., 2006), as well as a raw score higher than 3,9 on the scale for bulimia, taking into account the average score of non-clinical population (2.19) plus a standard deviation (1.71). The controls are represented by 88 individuals who have not had bulimic behaviors or any other behavior consistent with the diagnostic criteria for eating disorders, and had average scores on the EAT scale for bulimia below 2.19, as well as a general index on the EAT below 21 . 


\subsection{Instruments}

The instruments were: a Brazilian experimental scale to assess personality traits based on the Big Five theory; the Coping Response Inventory - Adult Form (CRI - A) for the evaluation of the perception of the problem and coping strategies; and the Eating Attitudes Test (EAT- 26) to assess behaviors consistent with eating disorders. All instruments have satisfactory psychometric data and were published in the Brazilian literature.

The scale of personality was used to evaluate two factors in our sample: neuroticism and extraversion. This test was based on the Personality Factor Inventory created by Pasquali, Ghesti and Azevedo (1997), which measures 15 psychological characteristics. The factors are divided into 25 phrases that participants should answer based on a Likert scale ranging from 1 (extremely uncharacteristic) to 5 (extremely characteristic). The items were preceded by a paragraph that asked participants to express their degree of agreement with each statement contained in the scale. This scale presents satisfactory psychometric characteristics, as described in Tomaz and Zanini (2009).

The Coping Response Inventory-Adult Form (Moos, 1993) measures eight specific coping strategies defined as Logical analysis, Positive Reappraisal, Seeking guidance and support, Problem solving, Cognitive avoidance, Acceptance-resignation, Seeking alternative rewards, and Emotional discharge. Each specific coping strategy comprises a six-item rating using a four-point Likert-type scale, ranging from 0 (No, not at all) to 3 (Yes, fairly often). The Cronbach alpha coefficients for Brazilian subjects are acceptable and ranged from 0,68 to 0,72. Similar Cronbach alpha coefficients are described in international coping literature (Moos, 1993).

Moos (1993) classified these specific strategies on the basis of Method or Focus of coping. The focus reflects the approach (directly coping with problems) versus avoidance coping (coping with the emotion elicited by the problem rather than the problem). Approach is composed of Logical Analysis, Positive Reappraisal, Seeking Guidance, and Problem Solving. Avoidance is composed of Cognitive Avoidance, Acceptance Resignation, Seeking Alternative Rewards, and Emotional Discharge. The method reflects a theoretical differentiation of cognitive versus behavioral efforts to cope. Cognitive method is composed of Logical Analysis, Positive Reappraisal, Cognitive Avoidance and Acceptance Resignation. Behavioral method is composed of Seeking Guidance, Problem Solving, Seeking Alternative Rewards and Emotional Discharge. These classifications allow to consider four typologies of coping: Approach, Avoidance, Cognitive and Behavioral coping, each of them rated from $0-72$.

To assess eating attitudes and behaviors characteristic of people suffering from eating disorders, we used the Eating Attitudes Test (EAT-26). This instrument has good psychometric qualities and has been used in several studies to assess behaviors related to eating disorders as well as diagnostic criteria for them (Cordás \& Neves, 2000). In this study we used the reduced version, which contains 26 items, divided into three ranges: diet; bulimic behaviors; and preoccupation with food and oral control (Freitas, Appolinario \& Gorenstein, 2002). Items are rated using a scale from 0 to 3 , in which the responses "always," "often" and "sometimes" punctuate 3, 2 and 1, respectively, but the responses "rarely", "almost never "and" never "do not give scores. Thus, individuals who achieve a score above 21 are classified as individuals with eating disorder behaviors (Nunes, Apollinario, Abuchaim, \& Coutinho, 2006). 


\subsection{Procedures}

The study was approved by the ethics in the human research committee and followed all the ethical procedures of the APA. The instrument application occurred collectively in the participants' classroom, coordinated by the researchers in charge. Data analysis was performed using the statistical package SPSS for Windows version 19.0.

\section{Results}

There were no significant differences in mean scores on the personality traits of extroversion $(\mathrm{p}=0.69)$ between cases $(\mathrm{M}=1.54, \mathrm{SD}=0.91)$ and controls $(\mathrm{M}=1.48, \mathrm{SD}=0,71)$, as well as for trait of neuroticism ( $\mathrm{p}=0.17$ ) for both groups $(\mathrm{M}=1.20$ and $1.42, \mathrm{SD}=0.99$ and 0.88 for cases and controls respectively) as shown in Table 1.

\begin{tabular}{c|c|c|c|c|c}
\hline Personality & Group & Means & SD & F & p. \\
\hline \multirow{2}{*}{ Extroversion } & Case & 1,54 & 0,91 & 0,16 & 0,69 \\
& Control & 1,48 & 0,71 & & \\
\multirow{2}{*}{ Neuroticism } & Case & 1,20 & 0,99 & 1,88 & 0,17 \\
& Control & 1,42 & 0,88 & & \\
\hline
\end{tabular}

Table 1. Means, Standard Deviation and compared means for personality in case and control groups.

However, although no significant differences were observed between the means of the personality traits, the data demonstrated a differential influence of these on coping strategies according to the group, as shown in Table 2. Table 2 shows Spearman correlation between coping strategies and personality traits neuroticism and extraversion for case and controls.

\begin{tabular}{lrrrrr}
\hline \multirow{2}{*}{ Escalas de Coping } & \multicolumn{2}{|c|}{ case } & \multicolumn{2}{c}{ Control } \\
\cline { 2 - 5 } & Extroversion & Neuroticism & Extroversion & Neuroticism \\
\hline Logical Analysis &, 248 &, 075 &, 000 &,- 125 \\
Positive Reappraisal &, $284^{*}$ &,- 149 &, 287 &,- 117 \\
Seeking Guidance &, $361^{*}$ &,- 088 &, $323^{*}$ &,- 084 \\
Problem Solving &, $314^{*}$ &,- 197 &, 088 &,- 120 \\
Cognitive Avoidance &,- 252 &,- 105 &, 038 &,- 114 \\
Acceptance/ Resignation &,- 106 &, 274 &, 157 &,- 077 \\
Seeking Alternative &, $356^{*}$ &,- 155 &, $314^{*}$ &,- 179 \\
Reward & & & & \\
Emotional Descharge &, 052 &, 086 & &, 137 &,- 051 \\
\hline
\end{tabular}

* Correlation is significant at the 0.05 level (2-tailed).

Table 2. Spearman correlation between coping strategies and personality traits neuroticism and extraversion for case and controls. 
In the case group, the personality trait of extroversion is associated with coping strategies such as positive reappraisal $(\mathrm{r}=0.28, \mathrm{p}<0.05)$, social support $(\mathrm{r}=0.36, \mathrm{p}<0.05)$, problem solving $(r=0.31, p<0.05)$ and seeking alternative reward $(r=0.36, p<0.05)$. In the control group, however, the extroversion trait is only associated with coping strategies as social support $(\mathrm{r}=0.32, \mathrm{p}<0.05)$ and seeking alternative reward $(\mathrm{r}=0.31, \mathrm{p}<0.05)$,

Table 3 shows data from compared mean between case and control groups for problem appraisal.

\begin{tabular}{|c|c|c|c|c|c|}
\hline Appraisal questions & Group & Mean & SD & $\mathbf{F}$ & $\mathbf{P}$ \\
\hline \multirow{2}{*}{ Previous experience with the problem } & case & 1,31 & 1,35 & \multirow[t]{2}{*}{0,44} & \multirow[t]{2}{*}{0,51} \\
\hline & control & 1,46 & 1,30 & & \\
\hline \multirow{2}{*}{ Knowing the problem would happened } & case & 1,73 & 1,38 & \multirow[t]{2}{*}{0,01} & \multirow[t]{2}{*}{0,92} \\
\hline & control & 1,76 & 1,29 & & \\
\hline \multirow{2}{*}{$\begin{array}{l}\text { Have enough time to prepare to cope with } \\
\text { the problem }\end{array}$} & case & 1,11 & 1,29 & \multirow[t]{2}{*}{4,84} & \multirow[t]{2}{*}{0,03} \\
\hline & control & 1,55 & 1,13 & & \\
\hline \multirow{2}{*}{ Thinking on the problem as a threat } & case & 1,84 & 1,30 & \multirow[t]{2}{*}{1,17} & \multirow[t]{2}{*}{0,28} \\
\hline & control & 2,06 & 1,15 & & \\
\hline \multirow{2}{*}{ Thinking on the problem as a challenge } & case & 1,73 & 1,34 & \multirow[t]{2}{*}{0,76} & \multirow[t]{2}{*}{0,39} \\
\hline & control & 1,91 & 1,20 & & \\
\hline \multirow{2}{*}{ If the problem were caused by yourself } & case & 1,23 & 1,27 & \multirow[t]{2}{*}{1,99} & \multirow[t]{2}{*}{0,16} \\
\hline & control & 1,91 & 1,20 & & \\
\hline \multirow{2}{*}{$\begin{array}{l}\text { If the problem were caused by other } \\
\text { person }\end{array}$} & case & 1,53 & 1,29 & \multirow[t]{2}{*}{0,12} & \multirow[t]{2}{*}{0,73} \\
\hline & control & 1,46 & 1,27 & & \\
\hline \multirow{2}{*}{$\begin{array}{l}\text { Positive consequences of facing the } \\
\text { problem }\end{array}$} & case & 1,82 & 1,35 & \multirow[t]{2}{*}{0,01} & \multirow[t]{2}{*}{0,92} \\
\hline & control & 1,84 & 1,15 & & \\
\hline \multirow{2}{*}{ If the problem were solved } & case & 1,18 & 1,32 & \multirow[t]{2}{*}{3,30} & \multirow[t]{2}{*}{0,08} \\
\hline & control & 1,57 & 1,25 & & \\
\hline \multirow{2}{*}{ If it were solved, is everything all right } & case & 1,47 & 1,30 & \multirow[t]{2}{*}{4,07} & \multirow[t]{2}{*}{0,05} \\
\hline & control & 1,87 & 1,10 & & \\
\hline
\end{tabular}

Table 3. Mean, Standard Deviation and Compared mean between case and controls for problem appraisal.

The control group tends to evaluate having enough time to prepare to cope with the problem significantly more $(\mathrm{p}=0.03)$ than the case group $(\mathrm{m}=1.55$ and $1.11, \mathrm{SD}=1.13$ and 1,29 for the case and control group respectively). They also tend to evaluate that the problem was solved $(p=0,08, F=3,30)$ and that everything is all right now $(p=0,05, F=4,07)$ in levels higher than did the case group $(\mathrm{m}=1,57$ and $1,18, \mathrm{SD}=1,25$ and 1,32 for control and case group respectively for if the problem was solved; $\mathrm{m}=1,87$ and $1,47, \mathrm{SD}=1,10$ and 1,30 for control and case group respectively for everything is all right now). 
Table 4 shows data from Spearman correlation between personality trait and problem appraisal for case and control groups.

In the control group, the personality trait of neuroticism is associated with the appraisal of the problem as a threat. Thus, in this group, individuals with higher neuroticism personality trait tend to appraise more experiencing the problem as a threat $(r=0.20, p<0.05)$.

In the group of cases, however, the personality trait of extroversion was positively associated with the evaluation that the problem is already solved $(r=0.26, p<0.05)$ and if it is solved, things are alright $(\mathrm{r}=0.39, \mathrm{p}<0.01)$, while the personality trait neuroticism was negatively associated with the evaluation that, once the problem is solved, things will already be alright $(\mathrm{r}=-0.31, \mathrm{p}<0,05)$. Thus, in the group case, a higher score on the personality traits of extroversion is associated with a perception that problems are solved and once solved, things are going well, while those individuals belonging to this group with the highest scores in trait neuroticism tend to evaluate that, although having solved the problem, things are not going well again.

\begin{tabular}{l|c|c|c|c}
\hline \multicolumn{1}{c|}{ Appraisal questions } & \multicolumn{2}{c|}{ case } & \multicolumn{2}{c}{ Control } \\
& $\begin{array}{c}\text { Extroversi } \\
\text { on }\end{array}$ & $\begin{array}{c}\text { Neuroti } \\
\text { cism }\end{array}$ & $\begin{array}{c}\text { Extrover } \\
\text { sion }\end{array}$ & $\begin{array}{c}\text { Neuroti } \\
\text { Cism }\end{array}$ \\
\hline Previous experience with the problem & 0,22 & 0,11 & 0,95 & $-0,01$ \\
Knowing the problem would happen & 0,28 & $-0,14$ & 0,01 & 0,20 \\
Having enough time to prepare to cope with & 0,17 & $-0,13$ & 0,15 & $-0,01$ \\
the problem & 0,18 & 0,11 & 0,12 & $0,20^{*}$ \\
Thinking on the problem as a threat & 0,25 & $-0,06$ & 0,14 & 0,03 \\
Thinking on the problem as a challenge & 0,07 & 0,21 & $-0,01$ & $-0,08$ \\
If the problem were caused by yourself & $-0,11$ & 0,12 & $-0,08$ & 0,00 \\
If the problem were caused by another person & $-0,03$ & $-0,10$ & $-0,03$ & 0,08 \\
Positive consequences of facing the problem & $0,26^{*}$ & $-0,15$ & 0,10 & $-0,09$ \\
If the problem were solved & $0,39^{* *}$ & $-0,31^{*}$ & 0,06 & $-0,14$ \\
If it were solved, is everything all right?
\end{tabular}

* significant at a level of $\mathrm{p} \leq 0,05$.

** significant at a level of $\mathrm{p} \leq 0,01$.

Table 4. Spearman correlation between assessment of the problem and personality traits neuroticism and extraversion for case and controls.

\section{Conclusion}

In Psychology, the idea of an association between eating disorders and personality traits has already been demonstrated (Binford, 2003; Gongora, Guedes, Albuquerque , Troccoli, Noriega, \& Guedes, 2006; Rebelo \& Leal, 2007). However, this study found no significant differences between the personality traits of people with and without bulimic behaviors. Despite the fact the differences do not present statistically representative values within the averages found in this study, it can be postulated that the size of the clinical sample used 
may have contributed to minimize the statistical effect of this difference between the groups. Therefore studies with a larger number of subjects and using other instruments could demonstrate a significant difference, since this study uses a small sample size and a cross sectional data collection. However, beside that, data shows that bulimic subjects are less neurotic and more extroverted when compared with general population. That is of interesting especially because, in some sense, it demonstrate a common sense that obese people are more extroverted than others. That could be of interested for future studies.

Nevertheless, the data seems to indicate that, although this difference was not significant between both groups, the influence of personality traits on the perception of the problem as well as on ways of coping with problems occurs differentially. Thus, although no significant difference was observed between personality traits of both groups, this small difference seems to produce differential relations in perceptions and behaviors of individuals when dealing with their problems. The data is discussed in the light of coping and personality theories. We also discuss the need for psychological interventions based on the development of coping skills and geared towards the care of patients with bulimia.

We also discuss the need for psychological interventions directed towards the care of patients with bulimia that direct their aims to the development of coping abilities, which will widen their behavioral repertoire regarding ways of facing problems, and which may lead to changes in the ways of perceiving and relating to the environment, as well as higher assertiveness in order to develop a stronger emotional self-control and self-confidence.

\section{References}

Binford, R. B. (2003). Implementation and predictive capacity of CBT Coping in individuals with bulimia nervosa. Tese de doutorado não publicada, Universidade de Minnesota, Estados Unidos.

Blumenthal, J. A., Babyak, M. A., Carney, R. M., Keefe, F. J., Davis, R. D., LaCaille, R., Parekh, P. I., Freedland, K. E., Trulock, E., \& Palmer, S. M. (2006). Telephonebased coping skills training for patients awaiting lung transplantation: The INSPIRE study. Journal of Consulting and Clinical Psychology, ISSN 0022-006X, 74, 535-544.

Castilho, Simone Mancini, Gonçalves, Simone Brunhani, Leite, Marcos da Costa, Segal, Adriano \& Cordás, Táki Athanássios (1995). Bulimia nervosa III: disorders and personality evaluation in patients with bulimia nervosa. Jornal Brasileiro de Psiquiatria, ISSN 0047-2085, 44, 32-37.

Claudino, A. M., \& Zanella, M. T. (2005). Transtornos Alimentares e Obesidade. Barueri: Manole, ISBN: 8520422675.

Compas, B. E. (1987). Coping With Stress During Childhood and Adolescence. Psychological Bulletin, ISSN 1641-7844, 101, 393-403.

Connor-Smith, J. K., \& Flachsbart, C. (2007). Relations Between Personality and Coping: A Meta-Analysis. Journal of Personality and Social Psychology, ISSN 0022-3514, 93, 1080-1107.

Cordás, T. A., \& Neves, J. E. P. (2000). Escalas de avaliação de transtornos alimentares. Em C. Gorenstein, L. H. S. G. Andrade \& A. W. Zuardi (Orgs.), Escalas de avaliação em 
psiquiatria e psicofarmacologia (pp. 345-347). São Paulo: Lemos-Editorial, ISSN 0104-7795.

Cordás, T. A. (2004). Transtornos alimentares: classificação e diagnóstico. Revista de Psiquiatria Clínica, ISSN 0101-6083, 31, 154-157.

Costa, P. T., Somerfield, M. R., \& McCrae, R. R. (1996). Personality and Health. En L. Pervin (Ed.). Handbook of personality theory and research. London: Guilford Press, ISBN: 1593858361.

Costa, P. T., \& Widiger, T. A. (1993). Introduction. Em P. T. Costa \& T. A. Widiger (Orgs.), Personality Disorders and the Five-Factor Model of Personality (pp. 1-10). Whashington, DC: American Psychological Association, ISSN: 0003-066X.

Chemin, C. \& Milito, F. (2007). Transtornos Alimentares em Adolescentes. Revista Brasileira de Obesidade, Nutrição e Emagrecimento, ISSN 1981-9919, 1, 84-88.

Freitas, S., Gorenstein, C., \& Appolinario, J. C. (2002). Instrumentos para a avaliação dos transtornos alimentares. Revista de Psiquiatria, ISSN 0101-8108, 24, 34-38.

Furtado, E. S., Falcone, E. M. O., \& Clark, C. (2003). Avaliação do estresse e das habilidades sociais na experiência acadêmica de estudantes de medicina de uma universidade do Rio de Janeiro. Interação em Psicologia, ISSN 1981-8076 ,7, 43-51.

Gómez-Fraguela, J. A. Luengo-Martín, A. Romero-Triñanes, E. Villar-Torres P. \& Sobral-Fernández, J. (2006). Estratégias de afrontamiento en el inicio de la adolescencia y su relación con el consumo de drogas y la conducta problemática. International Journal of Clinical and Health Psychology, ISSN 16972600, 6, 581-597.

Gongora, V. C., van de Staak, C. P. F., \& Derksen, J. J. L. (2004). Personality Disorders, Depression and Coping Styles in the Argentinean Bulimic Patients. Journal of Personality Disorders, ISSN 0885-579X ,18, 272-285.

Gregor, M. M. (2005). The effect of acceptance and nonacceptance based coping strategies on symptom severity in the Eating Attitudes Test (EAT). Tese de Doutorado não publicada, Faculty of the Chicago School of Professional Psychology, Chicago.

Griffith, M. A., Dubow, E. F., \& Ippolito, M. F. (2000). Developmental and cross-situational differences in adolescent's coping strategies. Journal of Youth and Adolescence, ISSN 0047-2891, 29, 183-197.

Guedea, M. T. D., Albuquerque, F. J. B., Tróccoli, B. T., Noriega, J. A. V., Seabra, M. A. B., \& Guedea, R. L. D. (2006). Relação do bem-estar subjetivo, estratégias de enfrentamento e apoio social em idosos. Psicologia: Reflexão e Crítica, ISSN 01027972, 19, 301-308.

Holahan, C. J., Moos, R. H., \& Schaefer, J. A. (1996). Coping, Stress Resistance, and Growth: Conceptualization adaptive functioning. Em M . Zeidner \& N. S. Endler, (Orgs.), Handbook of Coping: theory, research, applications (pp. 24-43). New York- EUA: John Wiley \& Sons, ISBN 978-0-471-59946-3.

Hutz, C. S., \& Nunes, C. H. S. S. (2001). Escala fatorial de neuroticismo. São Paulo, SP: Casa do Psicólogo.

Lazarus, R. S., \& Folkman, S. (1984). Stress, Appraisal and Coping. New York: Springer, ISBN 0826141919. 
Leonidas, C., \& Santos, M. A. D. ( 2010). A Avaliação da Imagem Corporal e Atitudes Alimentares de Pacientes com Anorexia Nervosa. Aconselhamento na Saúde: perspectivas integradoras, ISBN/ISSN 0874.0283, 1, 261-277.

Margis, R., Picon, P., Cosner, A. F., \& Silveira, R. O. (2003). Relação entre estressores, estresse e ansiedade. Revista de Psiquiatria RS, ISSN 0101-8108, 25, 65-74.

Moos, R. H. (1993). Coping Response Inventory Adult Form - ProfessionalManual. Odessa, Flórida: PAR Psychological Assessment Resources, Inc, ISBN 0911907068.

Nakahara R; Yoshiuchi K; Yamanaka G; Sasaki T; Suematsu H \& Kuboki T. (2000). Coping skills in Japanese women with eating disorders. Psychological Reports, ISSN 00332941, 87, 741-746.

Nunes, C. H. S. S. (2005). Construção, normatização e validação das escalas de socialização e extroversão no modelo dos Cinco Grandes Fatores. Tese de Doutorado não publicada, Instituto de Psicologia, Universidade Federal do Rio Grande do Sul, Porto Alegre.

Nunes, C. H. S. S., \& Hutz, C. S. (2007). Construção e validação da escala fatorial de socialização no modelo dos Cinco Grandes Fatores de Personalidade. Psicologia: Reflexão e Crítica, ISSN 0102-7972, 20, 20-25.

Nunes, M. A. A., Apolinário, J. C., Abuchaim, A. L. G., \& Coutinho, W. (2006). Transtornos alimentares e obesidade. Porto Alegre: Artmed, ISBN 9788536306773.

Pasquali, L., Azevedo, A. M., \& Ghesti, I. (1997). Manual Técnico do Inventário Fatorial de Personalidade. São Paulo: Casa do Psicólogo, ISBN: 8585141913.

Pesce, R. P., Assis, S. G., Santos N., \& Oliveira, R. V. C. (2004). Risco e proteção: em busca de um equilíbrio promotor de resiliência. Psicologia: Teoria e Pesquisa, ISSN 0102$3772,20,135-143$.

Rebelo, A., \& Leal, I. (2007). Fatores de Personalidade e Comportamento Alimentar em Mulheres Portuguesas com Obesidade Mórbida: Estudo Exploratório. Análise Psicológica, ISSN 0870-8231, 3, 467-477.

Rowe, M. M. (2006). Four-year Longitudinal Study of Behavioral Changes in Coping With Stress. American Journal Health Behavior, ISSN 1945-7357, 30, 602-612.

Ruiz, V. M., \& Jiménez, J. A. (2004). Estructura de la personalidad: Ortogonalidad versus oblicuidad. Anales de Psicología, ISSN 1695-2294, 20, 1-13.

Sicchieri, J. M. F., Bighetti, F., Borges, N. J. B. G., Santos, J. E. D., Ribeiro, \& R. P. P. (2006). Manejo Nutricional nos Transtornos Alimentares. Simpósio Transtornos Alimentares: Anorexia e Bulimia Nervosas, ISSN 1676-7314, 39 (3): 371-4.

Souza, L. V., \& Santos, M. A. (2007). Anorexia e bulimia: Conversando com as famílias. São Paulo: Vetor.

Sorkin, D. H., \& Rook, K. S. (2006). Dealing With Negative Social Exchanges in Later Life: Coping Response, Goals, and Effectiveness. Psychology and Aging, ISSN: 08827974, 21, 715-725.

Tani, F., Greenman, P. S., Schneider, B. H., \& Fregoso, M. (2003). Bullying and the Big Five: A study of childhood personality and participant roles in bullying incidents. School Psychology International, ISSN: 1461-7374, 24, 131-146.

Tobin, D. L. ( 2004). Terapia de Estratégias para Combater a Bulimia Nervosa. São Paulo: Roca, ISBN: 85- 7241-485-1. 
Tomaz, R., \& Zanini, D. S. (2009). Personalidade e Coping em Pacientes com Transtornos Alimentares e Obesidade. Psicologia: Reflexão e Crítica. ISSN 0102-7972, 22, 447454 . 


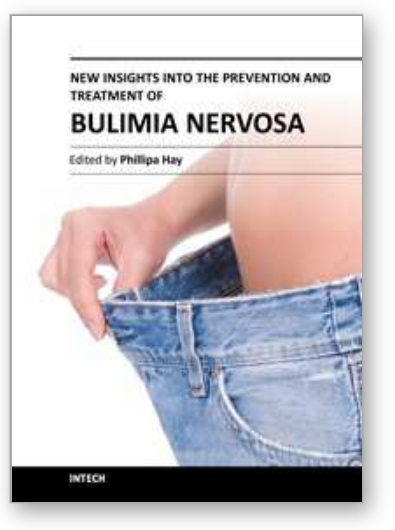

\author{
New Insights into the Prevention and Treatment of Bulimia Nervosa \\ Edited by Prof. Phillipa Hay
}

ISBN 978-953-307-767-3

Hard cover, 190 pages

Publisher InTech

Published online 03, October, 2011

Published in print edition October, 2011

Bulimia nervosa and eating disorders are common cause of distress and health related burden for young women and men. Despite major advances over the past three decades many patients come late to treatment and find that the therapy is incompletely addressed to the complex psychopathology and co-morbidities of the illness. The present book brings timely and contemporary understandings of bulimia nervosa to aid in current thinking regarding prevention and treatment. It will be read by therapists interested in enhancing their current approaches and those interested in earlier and more effective prevention and closing the gap between illness onset and accessing treatment. They will find practical guidance but also new ideas and ways of thinking about bulimia nervosa and the illness experience in this book.

\title{
How to reference
}

In order to correctly reference this scholarly work, feel free to copy and paste the following:

Tomaz Renata and Zanini Daniela S (2011). Personality and Coping in Groups With and Without Bulimic Behaviors, New Insights into the Prevention and Treatment of Bulimia Nervosa, Prof. Phillipa Hay (Ed.), ISBN: 978-953-307-767-3, InTech, Available from: http://www.intechopen.com/books/new-insights-into-theprevention-and-treatment-of-bulimia-nervosa/personality-and-coping-in-groups-with-and-without-bulimicbehaviors

\section{INTECH}

open science | open minds

\author{
InTech Europe \\ University Campus STeP Ri \\ Slavka Krautzeka 83/A \\ 51000 Rijeka, Croatia \\ Phone: +385 (51) 770447 \\ Fax: +385 (51) 686166 \\ www.intechopen.com
}

\author{
InTech China \\ Unit 405, Office Block, Hotel Equatorial Shanghai \\ No.65, Yan An Road (West), Shanghai, 200040, China \\ 中国上海市延安西路65号上海国际贵都大饭店办公楼 405 单元 \\ Phone: +86-21-62489820 \\ Fax: +86-21-62489821
}


(C) 2011 The Author(s). Licensee IntechOpen. This is an open access article distributed under the terms of the Creative Commons Attribution 3.0 License, which permits unrestricted use, distribution, and reproduction in any medium, provided the original work is properly cited. 